\title{
MAGNET PAKET WISATA DALAM MENARIK KUNJUNGAN WISATAWAN ASING BERKUNJUNG KE YOGYAKARTA
}

\author{
Erlangga Brahmanto \\ Dosen Perhotelan AKPAR "BSI Yogyakarta" \\ Email : erlangga.egb@bsi.ac.id
}

\begin{abstract}
Tourism is inseparable from the role of the Travel Agent. The role of travel agents is vital due to the creativity of " concocting " tour packages offered by the travel agent that makes the magnetic allure of foreign tourists come to Yogyakarta. With more and more of her as a tourist destination has to offer and the more diverse types paketan tour at an economical price, then the scene of a race between a travel agent - travel agent in Yogyakarta to captivate foreign tourists to come to Yogyakarta .

ASITA ( Association of Indonesian Tours And Travel) is a forum All Indonesia Tour \& Travel Yogyakarta chapter, noting that there is a trend of foreign tourists visit it depends on the package tours offered by travel agents. Offered more competitive prices which makes the competition between travel agents with one anothe. Many factors affect the motivation of an individual or a group of tourists who come to Yogyakarta.
\end{abstract}

Keywords : Travel agent, Market segmentation

\section{PENDAHULUAN}

Obyek Wisata Yang terdapat di Indonesia sudah diakui oleh negara - negara di dunia. Dalam era globalisasi saat ini sektor pariwisata merupakan industri terbesar dan terkuat dalam pembiayaan ekonomi global. Sektor pariwisata akan menjadi pendorong utama perekonomian dunia pada abad ke21, dan menjadi salah satu industri yang mengglobal. Pariwisata telah memberikan devisa yang cukup besar bagi berbagai negara. Indonesia sebagai negara kepulauan terbesar di dunia yang terdiri dari 17.508 pulau atau disebut juga sebagai nusantara atau negara maritim, telah menyadari pentingnya sektor pariwisata terhadap perekonomian Indonesia dikarenakan pertumbuhan pariwisata Indonesia selalu di atas pertumbuhan ekonomi Indonesia.

Pengembangan pariwisata yang telah dilakukan baik oleh pemerintah maupun swasta telah meningkatkan jumlah kedatangan wisatawan baik lokal maupun dari Negara lain. Menurut Spilane (1987) pariwisata adalah "perjalanan dari suatu tempat ke tempat lain, bersifat sementara, dilakukan perorangan maupun kelompok, sebagai usaha mencari keseimbangan atau keserasian dan kebahagiaan dengan lingkungan hidup dalam dimensi sosial, budaya, alam dan ilmu". Ditambah pula bahwa pariwisata terbagi atas beberapa jenis, yaitu: (1) pariwisata untuk menikmati perjalanan (pleasure tourism); (2) pariwisata untuk berekreasi (recreation tourism); (3) pariwisata untuk budaya (culture tourism); (4) pariwisata untuk olah raga (sport tourism); (5) pariwisata untuk urusan usaha dagang (business tourism); dan (6) pariwisata untuk berkonvensi ( convention tourism ).

Fandeli (1995) mengemukakan bahwa "pariwisata adalah segala sesuatu yang berkaitan dengan wisata, termasuk pengusahaan obyek daya tarik wisata serta usaha usaha yang terkait di bidang tersebut. Dijelaskan pula bahwa wisata 
merupakan suatu kegiatan bepergian dari suatu tempat ke tempat tujuan lain di luar tempat tinggalnya, dengan maksud bukan untuk mencari nafkah, melainkan untuk menciptakan kembali kesegaran baik fisik maupun psikis agar dapat berprestasi lagi. Sementara itu menurut Pendit (1990), pariwisata merupakan suatu sektor yang kompleks, yang juga melibatkan industry industri klasik, seperti kerajinan tangan dan cinderamata, serta usaha usaha penginapan, restoran dan transportasi. Dalam menarik wisatawan, maka diperlukan kreatifitas meramu paket paket wisata yang menarik. Dengan adanya paket wisata ini diharapkan mampu mendatangkan wisatawan dari luar negri lebih banyak dibandingkan tahun tahun yang lalu. Dengan adanya permasalahan ini, penulis tertarik meneliti.

\section{LANDASAN TEORI}

Pengertian pariwisata menurut Pendit pariwisata adalah kegiatan orang-orang sementara dalam jangka waktu pendek, ketempat-tempat tujuan di luar tempat tinggalnya dan tempat bekerjanya, serta di luar kegiatan- kagiatan mereka, dan selama di tempat tujuan mempunyai berbagai maksud, termasuk kunjungan wisata.

Biro perjalanan adalah kegiatan usaha yang bersifat komersial yang mengatur, dan menyediakan pelayanan bagi seseorang, sekelompok orang, untuk melakukan perjalanan dengan tujuan utama berwisata

Masih menurut Pendit, Biro perjalanan wisata adalah perusahaan yang memiliki tujuan untuk menyiapkan suatu perjalanan bagi seseorang yang merencanakan untuk mengadakanya.Paket wisata adalah suatu rencana kegiatan wisata yang telah disusun secara tetap dengan harga tertentu yang mencakup transportasi, hotel atau akomodasi, obyek dan daya tarik wisata serta fasilitas penunjang lainnya yang tertera dalam perjanjian paket wisata tersebut.
Biro Perjalanan Wisata dalam fungsinya sebagai mediator dan pengelola dari keseluruhan komponen pariwisata yang dibutuhkan oleh wisatawan selam melakukan kegiatan perjalanan wisatanya, haruslah memperhatikan bahwa produk yang disusunnya dapat memenuhi fungsinya sebagai alat bantu wisatawan dalam memenuhi kebutuhannya akan istirahat dan santai untuk kebugaran jasmani dan rohani serta menghilangkan kebosanan terhadap pekerjaan atau kegiatan rutinnya yang diharapkan dapat mengembangkan personality, pengungkapan sikap, mental, fisik dan spiritual. Biro Perjalanan Wisata seyogyanya juga dapat menempatkan dirinya bukan hanya sebagai perantara saja melainkan sebagai partner perjalanan yang menyenangkan bagi wisatawan atas kepiawaiannya dalam mengelola perjalanan yang mampumemberikan bagus terutama dalam saving the time and money dan mampu memberikan rasa aman, nyaman maupun kepuasan wisatawan dalam kegiatan wisata yang dilakukannya. Sedangkan segmentasi pasar tersebut menurut Fandy Tjiptono segmentasi pasar adalah proses membagi pasar keseluruhan suatu produk atau jasa yang bersifat hiterogen ke dalam beberapa segmen, dimana masing-masing segmennya cenderung bersifat homogen dalam segala aspek. Jadi, segmen pasar merupakan penetapan oleh perusahaan secara jelas kelompok - kelompok pasar yang sesuai untuk dilayani, selain efektif dan efisien melalui kombinasi kebijakan marketing mix yang berbeda- beda antara segmen yang satu dengan segmen yang lain.

Beberapa cara untuk menyusun segmen pasar antara lain:

1. Berdasarkan geografis

yaitu pengelompokan pasar berdasarkan atas daerah atau wilayah seperti kebangsaan, provinsi, kota, desa dan sebagainya. Segmentasi geografik membagi pasar menjadi beberapa unit 
secara geografik seperti negara, regional, propinsi, kota, wilayah kecamatan, wilayah kelurahan dan kompleks perumahan.

Sebuah perusahaan mungkin memutuskan untuk beroperasi dalam satu atau beberapa wilayah geografik ini atau beroperasi di semua wilayah tetapi tidak memperhatikan kebutuhan dan keinginan psikologis konsumen. Banyak perusahaan dewasa ini "merigionalkan" program pemasaran produknya, dengan melokalkan produk, iklan, promosi dan usaha penjualan agar sesuai dengan kebutuhan masing-masing regional, kota, bahkan kompleks perumahan.

2. Berdasarkan demografis

Segmentasi pasar demografis membagi pasar menjadi kelompok berdasarkan pada variabel seperti jenis kelamin, umur, status perkawinan, jumlahkeluarga, umur anak, pendapatan, jabatan, lokasi geografi, mobilitas, kepemilikan rumah, pendidikan, agama, ras atau kebangsaan.

Faktor-faktor demografis ini merupakan dasar paling populer untuk membuat segmen kelompok konsumen.

Paket wisata (package tour, inclusive tour) diartikan sebagai suatu perjalanan wisata dengan satu atau lebih tujuan kunjungan yang disusun dari berbagai fasilitas perjalanan tertentu dalam suatu acara perjalanan yang tetap, serta dijual dengan harga tunggal yang menyangkut seluruh komponen dari perjalanan wisata. Sebelum memahami paket wisata, harus dipastikan apakah dalam rangkaian komponenkomponen wisata tersebut terdapat acara mengunjungi objek/atraksi wisata. Bila hanya paket perjalanan (transportasi) dan akomodasi saja, tidak dapat dikatakan paket tour.

Unsur-unsur yang terlibat dalam industri pariwisata meliputi hal-hal sebagai berikut (Pendit, 1994): a. Akomodasi, tempat seseorang untuk tinggal sementara.

b. Jasa Boga dan Restoran, industri jasa di bidang penyelenggaraan makanan dan minuman yang dikelola secara komersial.

c. Transportasi dan Jasa Angkutan, industri usaha jasa yang bergerak di bidang angkutan darat, laut dan udara.

d. Atraksi Wisata, kegiatan wisata yang dapat menarik perhatian wisatawan atau pengunjung.

e. Cinderamata (Souvenir), benda yang dijadikan kenang-kenangan untuk dibawa oleh wistawan pada saat kembali ke tempat asal.

f. Biro Perjalanan, badan usaha pelayanan semua proses perjalanan dari berangkat hingga kembali.

\section{METODE PENELITIAN}

Pengumpulan data menggunakan pendekatan studi observasi dan literature ( pustaka), yang bersumber langsung hasil riset observasi penelitian obyek juga bersumber dari sejumlah literature yang meliputi buku-buku yang dapat mendukung isi penulisan dan literature online ( situs website ) yang bersifat menambah wahana keilmuan sebagai penunjang topik pembahasan.

\section{PEMBAHASAN}

Tidak bisa dipungkiri bahwa setiap biro perjalanan wisata membuat paketan tour semenarik mungkin dan dengan harga yang bersaing antara satu biro perjalanan dengan biro perjalanan yang lain dalam satu provinsi. ASITA sebagai wadah asosiasi Tour \& Travel menghimbau kepada semua tour \& travel agar kreatif meramu paketan paketan tour agar wisatawan mancanegara semakin meningkat jumlahnya datang ke Yogyakarta.

Jepang menjadi satu negara yang dibidik Badan Promosi Pariwisata Kota Yogyakarta 
(BP2KY) untuk mempromosikan pariwisata Kota Yogyakarta. Sebab, dalam kurun waktu 2013 sampai dengan 2015 , negara ini masuk lima besar penyumbang wisatawan asing ke Kota Gudeg. Direktur Eksekutif BP2KY, Artin Wuriyani, mengatakan, hingga april 2015 jumlah kunjungan mencapai 27.047 orang. "Angka tersebut berasal dari kunjungan melalui pintu utama Bandara Adisucipto serta dari 19 pintu masuk utama ke Yogya," jelas Artin, Selasa (8/3/2015).

Melihat angka ini maka tour \& travel mulai melirik pasar wisatawan jepang sebagai segmentasi product tour mereka. Perusahaan Tour \& Travel mulai mencari obyek-obyek wisata yang diinginkan oleh customer dari jepang. Orang jepang suka dengan yogya karenaada wisata alam, wisata pantai, wisata budaya dan sekarang cenderung melebar ke wisata cindera mata. serta kode etik profesi kepariwisataan yang telah diratifikasi. Bentuk layanan ini menurut pasal 14 UU 10/Th2009 adalah Usaha Jasa Pramuwisata.

Fungsi dan Tugas Pramuwisata Dari pengertian tentang tourist guide, profesi ini berada di tengah dan memiliki fungsi yang dinamis, menjadi ujung tombak 'penghubung' industri pariwisata dimana sejak orang keluar untuk berwisata sejak itu dibutuhkan peran dari tugas-tugas seorang Guide. Organisasi HPI merupakan salah satu dari 46 anggota asosiasi dunia World Federation or Tourist Guide Associations (WFTGA). Fungsi terpenting Pemandu Wisata adalah menghubungkan wisatawan dengan pusat-pusat ikon destinasi dan khazanah budaya lokal. Seorang Guide adalah guru, pemimpin, informan, juru terang, wartawan, humas, pemandu, penerjemah, pendamping, penghibur, motivator, seniman bahkan sebagai pekerja budaya. Profesi Tourist Guide di samping bertugas pokok memandu wisatawan, ia mampu berperan lebih strategis bagi kemajuan industri pariwisata nasional.
Dalam sebuah Konferensi Guide SeDunia di Bali bulan Januari 2011, WFTGA menempatkan asosiasi pada peran ideal juga marketing system tak tergantikan, diprediksi era mendatang adalah terbukanya akses global pada Pariwisata Budaya dimana Nusantara menjadi titik penyangga peradaban dunia. Secara individu maupun organ kepemanduan HPI, teknik dan pemberdayaan profesional harus terus ditingkatkan. Selain tugas layanan sesuai Kode Etik Pramuwisata, menerangkan ditail obyek wisata serta destinasi lokal pada para wisatawan, tugas melekat mereka adalah sales marketer produkproduk pariwisata . Guide juga berperan ikut menjaga daya tarik wisata dari pelaku kerusakan (fandalisme). Yaitu perbuatan mengu- bah warna, bentuk, menghilangkan spesies tertentu, mencemarkan lingkungan, memindahkan, mengambil, menghancurkan, atau memusnahkan daya tarik wisata sehingga berakibat berkurang atau hilangnya keunikan, keindahan, dan nilai autentik suatu daya tarik wisata yang telah ditetapkan oleh Pemerintah.

Tugas Pemandu Wisata dan Pengusaha terkait lain bisa pula dirujuk dalam UU 10/Thn 2009 Pasal 20, bahwa setiap wisatawan berhak memperoleh : (a) informasi yang akurat mengenai daya tarik wisata; (b) pelayanan kepariwisataan sesuai dengan standar; (c) perlindungan hukum dan keamanan; (d) pelayanan kesehatan; (e) perlindungan hak pribadi; dan (f) perlindungan asuransi untuk kegiatan pariwisata yang berisiko tinggi. Yang tergolong "usaha pariwisata risiko tinggi", antara lain wisata selam, arung jeram, panjat tebing, permainan jet coaster, atau melihat satwa liar di alam bebas. Kondisi wisata 'telusur Goa' maupun karakteristik pantai yang memiliki risiko bagi kunjungan wisatawan perlu dipersiapkan dengan baik oleh pelaku lapangan terutama tersedianya Pemandu Wisata Khusus.

$$
\text { Dalam satu paket tour telah }
$$


dipersiapkan komponen - komponen yang akan membuat wisatawan asing terangsang dan ingin mencoba paketan tour dari tour \& travel. Ini yang menyebabkan berpengaruhnya kunjungan wisatawan asing ke Yogyakarta.Disparda DIY selalu berupaya mengembangkan daya tarik objek wisata, termasuk menggarap objek wisata baru. Sebab, bagaimana pun juga objek wisata baru harus digarap secara serius, sekaligus menggembangkan daya tarik objek wisata lama untuk meningkatkan kunjungan wisatawan," kata Kepala Disparda DIY Tazbir, di Yogyakarta, Senin (8/3). Dalam kesempatan yang sama, Tazbir juga mengatakan " potensi pariwisata di wilayah Provinsi DIY sangat melimpah, tidak hanya kekayaan alam dan panorama pantai yang menawan, tetapi juga adat istiadat yang sampai sekarang masih hidup dan dijaga kelestariannya oleh masyarakat termasuk kesenian tradisional dan kebudayaannya.

Edwin Ismedi menyebutkan di DIY juga memiliki fenomena alam yang langka, di antaranya gumuk pasir Pantai Parangtritis di Kabupaten Bantul, Eco karst di Kabupaten Gunungkidul, bangunan heritage, serta aneka barang kerajinan yang membuat DIY dijuluki 'surga wisata' baru bagi wisatawan.Apalagi, menurut dia, berbelanja dan berwisata di DIY dinilai oleh wisatawan sangat murah.

Namun, seiring kemajuan pariwisata daerah lain, terutama dalam mengembangkan destinasi wisata baru, kepariwisataan DIY tidak boleh diam, dan harus serius menggarap serta menggali objek wisata baru yang bisa mendatangkan banyak wisatawan,"

Dengan adanya paket tour /Tour Package yang sangat beraneka ragam jenisnya maka tidak menutup kemungkinan para wisatawan asing akan lebih banyak lagi yang masuk ke Yogyakarta. Yogyakarta adalah surga wisatawan setelah Bali karena sangat banyak obyek wisata yang bisa dikombinasikan dan di buat paketan tour yang menarik minat wisatawan asing.

\section{KESIMPULAN}

Berdasarkan pembahasan tentang paket wisata menjadi magnet penarik kunjungan wisatawan asing ke Yogyakarta bisa ditarik kesimpulan bahwa pembuatan paket wisata harus semenarik mungkin dengan mengkombinasikan antara wisata alam, wisata budaya dikombinasikan dengan belanja di artshop atau toko cinderamata agar para turis mengetahui barang barang khas Yogyakarta untuk dibawa ke negaranya masing - masing.

Selain itu juga cinderamata berfungsi sebagai media promosi yang bisa dijadikan alat promosi. Pembuatan paket wisata juga harus diimbangi dengan kualitas dari Sumber daya manusia dalam hal ini Guide atau pemandu wisata harus selalu meng update ataupun memperbaharui kompetensinya sebagai pemandu wisata agar tamu terkesan padanya karena turis apalagi dari jepang itu mengutamakan semboyan " first meet impression" atau kesan pertama bermula dengan Guide itu sangat mempengaruhi mood dari para wisatawan.

\section{DAFTAR PUSTAKA}

Badan Promosi Pariwisata Yogya Bidik Wisatawan Jepang - Tribun Jogja.

Tjiptono. Fandy, 2002. Pemasaran Jasa. Yogyakarta: Andi Offset Nyoman S. Pendit, 2006. Ilmu pariwisata sebuah pengantar perdana. Jakarta: Pradnya Paramita. 